\title{
Breeding Performance of Clarias Gariepinus Obtained From Nigerian Waters
}

\author{
Megbowon, $I^{1}$., Fashina-Bombata, H.A ${ }^{2}$, Akinwale, M.M-A ${ }^{1}$, Hammed, A.M ${ }^{2}$, \\ Okunade, O. ${ }^{1}$ and Mojekwu T.O ${ }^{1}$ \\ Nigerian Institute for Oceanography and Marine Research, Lagos \\ Fisheries Department, Lagos State University, Ojo, Lagos
}

\begin{abstract}
Nigeria is the largest producer of the mud catfish (Clarias gariepinus) in sub-Sahara Africa. However, most of the strains used in aquaculture have suffered from inbreeding and its consequences. This study was conducted to evaluate reproductive performance of wild strains of C. gariepinus from freshwater systems of Nigeria and compare with domesticated strain. Collection of broodstock for the study was made from the 6 geo-political zones of Nigeria namely: South-South, South-West, South-East, North-Central, North-East and North-West. The fish were conditioned, fed and spawned in the laboratory of Fishtech/Biotechnology Department of the Nigerian Institute for Oceanography and Marine Research, Lagos, Nigeria. The results revealed that collection from North-West (Kebbi state) had the highest values for fertilization (89.8 2.7), hatchability (81.8 \pm 4.9$)$ and survival (61.3 \pm 6.3$)$ among the wild strains. This was followed by North-East having $82.7 \pm 3.1 a, 79.7 \pm 8.1$ and $48.7 \pm 2.1$ respectively. The domesticated strain had the least of these indices: $64.8 \pm 9.5 b, 60.4 \pm 6.5$ and $41.0 \pm 3,8$ for fertilization, hatchability and survival respectively. Although previous study indicates high performance in terms of fertilization, hatchability and survival for North-west (Kebbi) strain of Clarias gariepinus, the growth performance after 30 days of rearing from egg was lower than other strains. Mean weight was $0.98 \mathrm{~g}$, maximum weight $4.06 \mathrm{~g}$ while minimum weight was $0.3 \mathrm{~g}$, with standard deviation of 0.3. Domesticated strain had average weight of $2.01 \mathrm{~g}$, maximum weight of $5.93 \mathrm{~g}$ and minimum of $0.64 \pm 0.21 \mathrm{lg}$. There was also significant difference $(\alpha=0.05)$ in the number of shooters produced by each strain. The domesticated strain had the highest number of shooters (25 \pm 5.7$)$ while the strain from Kebbi had the least

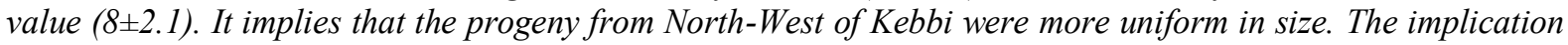
of the breeding potentials of Clarias geriepinus strain from Kebbi (high fertilization, hatchability and survival but poor growth), Oyo and Anambra (better growth but lower hatchability, fertilization and survival) is that if several selective breeding of these strains are carried out separately and the gene pool of Kebbi is combined with any of these two (Oyo and Anambra states), we are likely to obtain fish seed of better reproductive potential in terms of fertilization, hatchability, survival and better growth performance.
\end{abstract}

Key Word: Breeding, Performance, Clarias gariepinus, Nigerian Waters

\section{Introduction}

Today, aquaculture is the world's fastest-growing food-producing sector. According to FAO (2007), aquaculture continues to grow more rapidly than all other animal food-producing sectors, with an average global annual growth rate of $8.8 \%$ per year since 1970 , compared to only $1.2 \%$ for capture fisheries. There are a number of species with high culture potentials in Nigeria. However, the African Catfish (Clarias gariepinus) is widely considered as the leading cultured fish in the country. Some of the credentials of African catfish are: high growth rate reaching market size of $1 \mathrm{~kg}$ in 5-6 months under intensive management conditions: highly adaptable and resistant to handling and stress; can be artificially propagated by induced spawning techniques for reliable mass supply of fingerlings; commands a very high commercial value where it is highly cherished as food in Nigerian homes and hotels (Olaleye, 2005.).

This fish shows a seasonal gonadal maturation which is usually associated with the rainy season. The maturation processes of $C$. gariepinus in nature are generally influenced by annual changes in water temperature and photoperiodicity and the final triggering of spawning is usually caused by a raise in water level due to rainfall (de Graaf et al., 1995). The female African catfish has a fully developed ovary which contains "ripe" eggs all year round, if kept in ponds and water temperature kept above $22{ }^{\circ} \mathrm{C}$. The eggs of a "ripe" female make up $15-20 \%$ of the body weight. In captivity the African Catfish does not spawn spontaneously since the environmental factors such as the rise in water level and inundation of shallow areas do not occur on the fish farms. Under natural condition of spawning, lower hatching rates have been reported for Clarias gariepinus by various authors. de Graaf et al (1995) reported an average rate of $59.1 \%$ in the rainy season for C. gariepinus in the Republic of Congo, while Macharia et al (2005) reported a rate as low as $4 \%$ for C. gariepinus eggs incubated on a nylon substrate. Fertilization, hatching and early survival of larvae are vital for successful aquaculture of the African catfishes (Ataguba et al.,2009). 
The last twenty years has seen considerable gains in our knowledge concerning the reproduction and rearing of Clarias gariepinus. The present study was conducted to evaluate reproductive performance of wild strains of $C$. gariepinus from freshwater systems of Nigeria and compare with domesticated strain.

\section{COLLECTION OF BROODSTOCK}

\section{Materials And Methods}

The broodstock used for the study were collected from the 6 geo-political zone of Nigeria namely; South-west (Eleyele lake (N07 $26.2^{1}$ E $03^{0} 54.2^{1}$ ), Oba dam (N07 $23.5^{1}$ E0 $03^{0} 55.0^{1}$ ), South-East (Otuocha $\left(\mathrm{N} 06^{0} 20.2^{1} 006^{0} 50.3^{1}\right.$ ), Igbariam (N06 $23.5^{1} 00656.3^{1}$ ), South-South (Umuochi/Ona river (N06 ${ }^{0} 16.1^{1}$ E06 $^{0}$

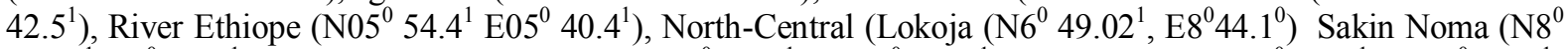
$12.13^{1} \mathrm{E}^{0} 24.2^{1}$ ), North-west (Argungun ( $12^{0} 44.6^{1}$; E004 $4^{0} 31.31^{1}$ ), River Niger (N11 $41.2^{1 ;}{\mathrm{E} 003^{0}}^{0} 37.3^{1}$ ) and North-East (Kiri lake (N09 $\left.61.2^{1} \mathrm{E}^{1} 2^{0} 28.5^{1}\right)$, Gerio lake $\left(\mathrm{N} 09^{0} 12.8^{0}\right.$ E $\left.12^{0} 28.6^{1}\right)$. The domesticated strain was collected from Lagos state as control. The fish were collected and conditioned for a week before feeding commenced which lasted for three months. Fish were fed coppens feed from the Netherlands at $3 \%$ of body weight twice daily.

\section{INDUCED SPAWNING AND STRIPPING}

The readiness of the female broodstock to be used for breeding was tested by holding fish in a head-up vertical position and a slight pressure was applied by pressing its abdomen with a thumb from the pectoral fin towards the genital papilla after which eggs ran out freely. The selected broodstock were kept separately in different tanks without feeding them, after they were injected with $0.35 \mathrm{ml}$ Ovaprim per $\mathrm{kg}$ live weight (Oyeleye and Omitogun, 2007) and then left for 10-12 hours latency period as a post ovulatory maturation period and to ensure high hatching rates and low proportion of deformed larvae (Hogendoorn, 1979).

\section{FERTILITY AND HATCHABILITY EVALUATION}

The development process from fertilized eggs to hatching is dependent upon water temperature while hatching rate is, next to egg quality, dependent on the water quality temperature, oxygen level, $\mathrm{pH}$ and water hardness. After stripping of the induced female broodstock, the eggs were weighed. The male was sacrificed to obtain the gonads which house the milt. The mixture of eggs and milt was stirred gently for about 1.0-2.0mins to allow contact and adequate fertilization. Within a few minutes after fertilization, the eggs absorbed water and could become sticky so the eggs were distributed in a netting suspended in the hatching trough $(50 \mathrm{~cm} \mathrm{x} 35 \mathrm{~cm} \mathrm{x}$ $30 \mathrm{~cm})$. The incubated eggs were monitored and temperature maintained between $26{ }^{\circ} \mathrm{C}-27{ }^{\circ} \mathrm{C}$ for incubation between $23-25 \mathrm{~h}$.

The percentage (\%) fertility and hatchability were determined subjectively after $12-15$ hours of fertilization by identifying the healthy developing eggs which were transparent green brownish in colour (Coppens, 2007) while the dead eggs were also estimated:

$$
\begin{aligned}
& \% \text { Fertility }=(\text { No. of fertilized eggs } / \text { No. of Extruded eggs }) \times 100 \% \\
& \% \text { Hatchability }=\frac{(\text { Total no. of fertilized eggs-Total no. of unfertilized eggs }) \times 100 \%}{\text { Total no. of fertilized eggs }}
\end{aligned}
$$

This was done by allowing the newly hatched larvae of all the treatments and that of the control to live on the remains of their yolk sacs for the first 2 days (Heicht et al.,1996) after hatching out of the eggs and thereafter carefully removed from the hatching troughs and were fed with Artemia (Inve Aquaculture, USA) on a regular basis (i.e., twice per day).

Irregularities in the activities of the fry in terms of feeding, movement in water was observed at the same time taking note of the dead fry which were removed immediately to avoid contamination of water. Survivability evaluation which was observed for a period of about $3-4$ weeks was done for each stage of the experiment together with fertility and hatchability for fresh (control experiment) and cryopreserved spermatozoa. The post-hatching survivability was evaluated as follows:

\section{$\%$ Survival $=($ Total no. of larvae- No. of dead larvae $)$ X100\% Total no. of larvae}

The data collected on the parameters, fertility and hatchability was subjected to standard statistical analysis. The data collected were analyzed using analysis of variance (ANOVA) to find a level of significance at $p<0.05$. 
III. Results

Table 1: Breeding Performance Of Clarias Gariepinus From Various Locations

\begin{tabular}{|c|c|c|c|c|c|}
\hline LOCATION & $\begin{array}{l}\text { WEIGHT OF } \\
\text { FEMALE }(\mathrm{g})\end{array}$ & WT.OF EGG (g) & $\begin{array}{c}\% \\
\text { FERTILIZATION }\end{array}$ & $\begin{array}{c}\% \\
\text { HATCHABILITY }\end{array}$ & $\begin{array}{l}\text { \% SURVIVAL } \\
\text { (30 DAYS) }\end{array}$ \\
\hline NORTH -CENTRAL & $406.5 \pm 10.6 b$ & $77.14 \pm 8.9 b$ & $69.2 \pm 4.3 \mathrm{a}$ & $59.8 \pm 6.2 \mathrm{~b}$ & $42.1 \pm 2.6$ \\
\hline NORTH-EAST & $706.9 \pm 16.8 \mathrm{a}$ & $122.81 \pm 14.8 \mathrm{a}$ & $82.7 \pm 3.1 \mathrm{a}$ & $79.7 \pm 8.1 \mathrm{a}$ & $48.7 \pm 2.1$ \\
\hline NORTH-WEST & $676.3 \pm 13.2 \mathrm{a}$ & $119.79 \pm 9.4 a$ & $89.8 \pm 2.7 a$ & $81.8 \pm 4.9 \mathrm{a}$ & $61.3 \pm 6.3$ \\
\hline SOUTH-WEST & $825.5 \pm 18.9 \mathrm{a}$ & $1437.9 \pm 5.7 \mathrm{a}$ & $73.6 \pm 6.3 a$ & $67.9 \pm 3.8 \mathrm{a}$ & $49.5 \pm 1.8$ \\
\hline SOUTH-EAST & $946.1 \pm 10.5 \mathrm{a}$ & $170.30 \pm 7.8 \mathrm{a}$ & $68.2 \pm 4.0 \mathrm{a}$ & $64.5 \pm 6.2 \mathrm{a}$ & $46.9 \pm 4.8$ \\
\hline SOUTH-SOUTH & $632.2 \pm 19.6 \mathrm{a}$ & $118.66 \pm 15.1 \mathrm{a}$ & $66.9 \pm 5.1 \mathrm{a}$ & $64.5 \pm 7.9 \mathrm{a}$ & $42.4 \pm 2.9$ \\
\hline DOMESTICATED & $980.2 \pm 23.1 \mathrm{a}$ & $164.9 \pm 23.2 \mathrm{~b}$ & $64.8 \pm 9.5 b$ & $60.4 \pm 6.5 b$ & $41.0 \pm 3,8$ \\
\hline
\end{tabular}

Means in each row with same superscript were not significantly different $(\mathrm{P}>0.05)$

The result revealed that collection from North-West (Kebbi state) had the highest values for fertilization $(89.8 \pm 2.7 \mathrm{a})$, hatchability $(81.8 \pm 4.9 \mathrm{a})$ and survival $(61.3 \pm 6.3)$ among the wild strains. This was followed by North-East having $82.7 \pm 3.1 \mathrm{a}, 79.7 \pm 8.1 \mathrm{a}$ and $48.7 \pm 2.1$ respectively. The domesticated strain had the least of these indices: $64.8 \pm 9.5 \mathrm{~b}, 60.4 \pm 6.5 \mathrm{~b}$ and $41.0 \pm 3.8$ for fertilization, hatchability and survival respectively. The result in table 2 showed that, although previous study indicates high performance in terms of fertilization, hatchability and survival for North-west (Kebbi) strain of Clarias gariepinus, the growth performance after 30 days of rearing from egg was lower than other strains. Mean weight was $0.98 \mathrm{~g}$, maximum weight $4.06 \mathrm{~g}$ while minimum weight was $0.3 \mathrm{~g}$, with standard deviation of 0.3 . Domesticated strain had average weight of $2.01 \mathrm{~g}$, maximum weight of $5.93 \mathrm{~g}$ and minimum of $0.64 \mathrm{~g}$ with standard deviation of 0.21 . There was also significant difference $(\alpha=0.05)$ in the number of shooters produced by each strain. The domesticated strain had the highest

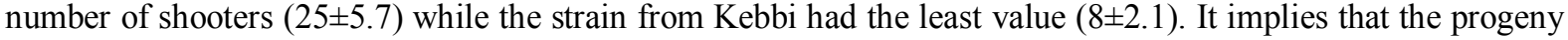
from North-West of Kebbi were more uniform in size.

TABLE 2: GROWTH PERFORMANCE OF CLARIAS GARIEPINUS FRY RAISED OVER 30 DAYS IN PLASTIC TANKS

\begin{tabular}{|c|c|c|c|c|c|c|}
\hline LOCATION & COORDINATE & $\begin{array}{l}\text { MAX. WT } \\
\text { OF FISH (g) }\end{array}$ & $\begin{array}{l}\text { MIN. WT } \\
\text { OF FISH } \\
\text { (g) }\end{array}$ & $\begin{array}{l}\text { AVE. WT. } \\
\text { OF FISH } \\
\text { (g) }\end{array}$ & $\begin{array}{l}\text { STD. } \\
\text { DEVIATION }\end{array}$ & $\begin{array}{l}\text { AV. NO. } \\
\text { OF } \\
\text { SHOOTERS }\end{array}$ \\
\hline $\begin{array}{l}\text { NORTH - } \\
\text { CENTRAL (Kogi) }\end{array}$ & $\begin{array}{l}\text { Lokoja }\left(\mathrm{N}^{0}\right. \\
\left.49.02^{1}, \mathrm{E}^{0} 44.1^{0}\right) \\
\text { Sakin Noma } \\
\left(\mathrm{N} 8^{0} 12.13^{1} \mathrm{E}^{0}\right. \\
24.2^{1)}\end{array}$ & 4.15 & 0.32 & 1.02 & 0.16 & $19 \pm 3.1$ \\
\hline $\begin{array}{l}\text { NORTH-EAST } \\
\text { (Adamawa) }\end{array}$ & $\begin{array}{l}\text { Kiri lake }\left(\mathrm{N} 09^{0}\right. \\
\left.61.2^{1} \text { E } 12^{0} 28.5^{1}\right) \\
\text { Gerio lake }\left(\mathrm{N} 09^{0}\right. \\
12.8^{0} \text { E } 12^{0} \\
\left.28.6^{1}\right)\end{array}$ & 4.06 & 0.30 & 0.98 & 0.30 & $15 \pm 4.2$ \\
\hline $\begin{array}{l}\text { NORTH-WEST } \\
\text { (Kebbi) }\end{array}$ & $\begin{array}{l}\text { Argungun } \\
\left(\mathrm{N} 12^{0} 44.6^{1}\right. \\
\text { E004 } \\
\text { River Niger } \\
\left(\mathrm{N} 11^{0} 41.1^{1}\right) \\
\text { E003 } \\
\left.00373^{1}\right)\end{array}$ & 3.32 & 0.28 & 0.85 & 0.07 & $8 \pm 2.1$ \\
\hline $\begin{array}{l}\text { SOUTH-WEST } \\
(\text { Oyo) }\end{array}$ & $\begin{array}{l}\text { Eleyele lake } \\
\left(\mathrm{N} 07^{0} 26.2^{1}\right. \\
\left.\mathrm{E} 03^{0} 54.2^{1}\right) \\
\text { Oba dam }\left(\mathrm{N} 07^{0}\right. \\
\left.23.5^{1} \mathrm{E}^{0} 3^{0} 55.0^{1}\right)\end{array}$ & 4.96 & 0.43 & 1.12 & 0.14 & $19 \pm 5,9$ \\
\hline $\begin{array}{l}\text { SOUTH-EAST } \\
\text { (Anambra) }\end{array}$ & $\begin{array}{l}\text { Otuocha (N06 } \\
\left.20.2^{1} 006^{0} 50.3^{1}\right) \\
\text { Igbariam }\left(\mathrm{N}^{1} 6^{0}\right. \\
\left.23.5^{1} 00656.3^{1}\right)\end{array}$ & 5.24 & 0.46 & 1.04 & 0.18 & $24 \pm 4.1$ \\
\hline $\begin{array}{l}\text { SOUTH-SOUTH } \\
\text { (Delta ) }\end{array}$ & $\begin{array}{l}\text { Umuochi/Ona } \\
\text { river }\left(\mathrm{N} 06^{0} 16.1^{1}\right. \\
\left.\text { E06 }^{0} 42.5^{1}\right) \\
\text { River Ethiope } \\
\left(\mathrm{N} 05^{0} 54.4^{1} \mathrm{E}^{1} 5^{0}\right. \\
\left.40.4^{1}\right)\end{array}$ & 4.96 & 0.41 & 1.21 & 0.11 & $17 \pm 6.2$ \\
\hline DOMESTICATED & Lagos & 5.93 & 0.64 & 2.01 & 0.21 & $25 \pm 5.7$ \\
\hline
\end{tabular}




\section{Discussion}

The finding revealed that collection from North-West (Kebbi state) had significantly $(\alpha=0.05)$ highest values for fertilization, hatchability and survival. This was followed by North-East and south-west. This higher value may probably due to the harsh weather of higher temperature in the North which made them adapt better under a seemingly conducive temperature of Lagos where the study was carried out. The maturation processes of $C$. gariepinus are generally influenced by annual changes in water temperature and photoperiodicity and the final triggering of spawning is caused by a raise in water level due to rainfall (de Graaf et al., 1995). The domesticated strain had the least values of fertilization, hatching and survival. Similarly, the strain from NorthWest (kebbi) also had the least size disparity as shown by the standard deviation. This implies that the progeny of this strain are more uniform.

The strain from Oyo and Anambra states grew better but hatchability and survival were low.

The implication of the breeding potentials of Clarias geriepinus strain from Kebbi (high fertilization, hatchability and survival but poor growth), Oyo and Anambra (better growth but lower hatchability, fertilization and survival) is that if several selective breeding of these strains are carried out separately and the gene pool of Kebbi is combined with any of these two (Oyo and Anambra states), we are likely to obtain fish seed of better reproductive potential in terms of fertilization, hatchability, survival and better growth performance. Such intra specific hybridization will lead to improved production as a result of combination of these production traits.

\section{References}

[1]. Ataguba, G. A, Annune, P.A. and Ogbe, F.G. (2009). Induced breeding and early growth of progeny from crosses between two African clariid fishes, Clarias gariepinus (Burchell) and Heterobranchus longifilis under hatchery conditions. Journal of Applied Biosciences (2009), Vol. 14: 755 - 760

[2]. Coppens International. (2009). www.coppens.eu.

[3]. de Graaf, G.J., Galemoni, F. and Banzoussi, B., 1995. The artificial reproduction and fingerling production of the African catfish Clarias gariepinus (Burchell 1822) in protected and unprotected ponds. Aquaculture Research 26: $233-242$.

[4]. Dunham, R.A., Majumdar, K., Hallerman, E., Bartley, D., Mair, G., Hulata, G., Liu, Z., Pongthana, N., Bakos, J., Penman, D., Gupta, M., Rothlisberg, P. \& Hoerstgen-Schwark, G. 2001. Review of the status of aquaculture genetics. In R.P. Subasinghe, P. Bueno, M.J. Phillips, C. Hough, S.E. McGladdery \& J.R. Arthur, eds. Aquaculture in the Third Millennium. Technical Proceedings of the Conference on Aquaculture in the Third Millennium, Bangkok, Thailand, 20-25 February 2000. pp. 137-166. NACA, Bangkok and FAO, Rome.

[5]. FAO, 2007. The State of World Fisheries and Aquaculture 2006. FAO Fisheries and AquacultureDepartment. Food and Agriculture Organization of the United Nations Rome, 2007. pp $5-22$

[6]. Hogendoorn H. (1979). Controlled propagation of the African catfish, Clarias lazera (C \& V).I. Reproductive biology and field experiments. Aquaculture Vol. 17 pp. 323-333.

[7]. Macharia SK, Ngugi CC, Rasowo J, 2005. Comparative Study of Hatching Rates of African Catfish (Clarias gariepinus Burchell 1822) Eggs on Different Substrates. NAGA, World Fish Center Quaterly 28 (3 \& 4): 23-26.

[8]. Olaleye, V.F. (2005). A review of reproduction and gamete management in the African catfish, Clarias gariepinus Ife Journal of Science Vol. 7 No.1 pp. 63- 70.

[9]. Oyeleye, O. O and Omitogun, O. G. (2007). Evaluation of motility of the short-term cryopreserved sperm of African giant catfish (Clarias gariepinus). Ife Journal of Agriculture Vol. 22 .No.(1) pp.11-16. Ile-Ife, Nigeria. ISSN 0331-6351. 